\title{
ISLAM DAN HAM
}

\section{(Tarik Menarik Antara Absolutisme dan Relativisme)}

\section{Roibin}

\section{Muqaddimah}

Méngamati secara cermat potret HAM yang berkembang dalam realitas masyarakat makro, nampaknya term tersebut belum bisa lepas dari teoriteori ilmuan yang dianggap masih memiliki relevansi. Sebagian kecil teori dimaksud adalah sebagaimana argumen yang tengah dilontarkan oleh konseptor biologi modern, Charles Dárwin, yang secara transparan menegaskan konsep "perjuangan untuk hidup". Menurutnya setiap individu harus bertempur melawan yang lain demi mempertahankan eksistensi dirinya (melangsungkan hidupnya), yang oleh beberapa kalangan upaya diatas biasa dikenal dengan teori seleksi alam Darwin. Proses seleksi alam inilah yang seringkali mampu, menjamin terpeliharanya species ataupun perbaikannya, karena dalam praktik kehidupan semisalnya, telah berlaku hukum siapa yang kuat dan mampu dialah yang akan dianggap barhasil.

Téori pengarang buku Orgin of species(1859) ini adalah ekuivalen biolohis dari filsafat borjuis yang didoktrinkan lewat persaingan bebas clalam memanifestasikan ekonominya, bahiwa perjuanagan bagi eksistensi telah menjelma menjadi perjuangan untuk memuaskán kebutuhan manusial(M.Luqman Hakiem,Ed, 1993 : 4)

Pengaruh teori ilmuan cliatas, terhadap eksistensi HAM tampak jelas sekali, jika kita sakssikan di beberapá - negara kuat kapitalisyang memuaiskan nafsunya untuk memangsa mayoritas negara-negara terbelakang di dunia ketiga. sehingga pertumbuhan selanjutnya dari negara-negara terbelakang tersebut tidlak pernati lepas dan bebas dari pantaưannya, utamanya pengaruh politik, ekonomi dan bưdaya yang selalu mencekam.
Mekanisme struktual yang secara sengaja tercipta ini, merupakan cara lain negara kuat kapitalis untuk memperkokoh kedudukannya sebaigai bangsa yang terseleksi melalui pertempuran, perlawanan dan pembelengguan kemanusialan, sehinggà species dan perbaikinnya akan berlangsung terus meskipun dipihak lain telah terdengar teriakan nestapa, yang menjeritkan penindasan terhadap kebebasan dan HAM mereka (Mohammad Arkoun : 199:294). Kasus ini bisa kita saksikan langsung clalam kasus penindasan etnis Bosnia oleh etis Serbia dan belakangan oleh etnis Kroatia. Sementara itu dalam potret yang lebih kecil bisa kita tengok dari berbagai tragedi cli negara kita yang baru-baru mencuat ke permukaan dengan mengatasnamakan HAM. Tentu penindasan ini telah terjadi relatif lama oleh etnis rezim orde baru, clan tidak lama kemudian tradisi itu telah terkoyak oleh suatu masa, pada saat mana angin kencang clemokratisasi telah beroperasi secara intens.

Menurut Luqman Hakiem clalam makalahnya ýng berjudul "Islam Tentang HAM" bahwa usatia-usaha historis untuk memecalikan problem kemanusiaan telalh dirintis sejak clini. Dan hampir tidak ditemui satu komentarpun yang bernada tidak antosias terhadap pentingnya citra manusia, kemerdekaan dan kebebasannya. Hal demikian terbukti sejak sebelum munculnya Universal Declaration of Human Right tahun 1948 yang lebih merupakan antiklimaks dari perang dunia kedua, sejumlah konstitusi regional telali muncul secara seporadis, yang dianggap sebagai mekanismemekanisme perintis ,seperti: Habeas Corpus Act,1679(Britaniá Raya); Bill of Rigbts (piagam Hakhak Virginia AS); Deklaration of Independence; 
Deklaration Desdroits de I'bomme et du citoyen(pernyataan HAM clan Warga Negara Perancis, 1789); The Four Freedoms(kebebasan Nan Empat,1941,Franklin Delano Roosevelt,AS); dan Piagam Perserikatan Bangsa-Bangsa clan Statua Mahkamah International ,sebagai bagian integralnya,(26 juni1945, SanFrasisco, Amerika Serikat); hingga berpuncak pada momentum dicetuskannya Deklarasi Universal oleh Sidlaing Umum Perserikatan Bangsa -bangsa di Istana Chailot, Paris, sebagai gayung yang berantai clari peristiwa(M. Luqman Hakiem, 1993:6).

Adalah suattu persoalan yang amat unik, disaat manusia sedang beramai-ramainya untuk melakukan pembelaan terhadlap HAM, disisi lain penindasan penyimpangan terhadlap HAM tersebut hampir menempati fragmentasi historis, dengan fenomina yang berulang kali: bahwa nasib HAM senantiasa menyuarakan . bagianbagian pembelalannya, atas musnalhnya kemerdekaan, keadlilan, persamaan, perdamaian dan persaudlaraan itu sendiri.

Mengapa hal ini bisa terjadi?

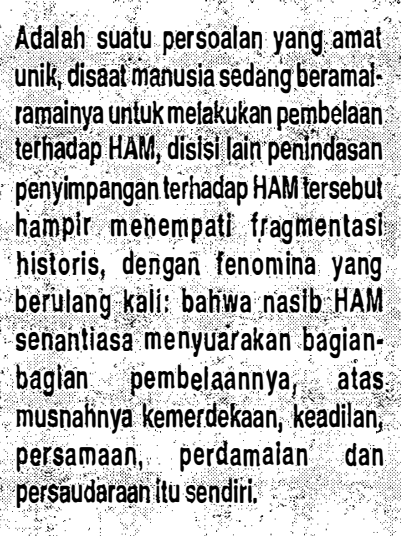

\section{Potret HAM dan Problematikanya}

Akuniulasi clari berbagai persoalan yang mengedepan diatas menurut hemat penulis merupakan persoalan esensial clalam eksistensi HAM. Untuk mengomenteri clari berbagai pertanyaan cliatas paling ticlak kital harus merujuk ulang mencari konsep hakiki tentang HAM itu sendiri. Apakah ia bersifat abadi(universall)yang diberlakukan sama untuk seluruh umat manusia cliclunia ini, ataukah masing-masing negara akan memiliki konsep. HAM yang berbedabeda?? Jika asumsi yang terakhir ini benar, bukankah konsep HAM pádla giliranya akan ditentukan oleh masing-masng individlu? semuanya serba memungkinkan, itulaih jawaban singkatnya. Namu betapa kemajemukan clan pluralitas konsep HAM yang muncul dari indlividu akan selalu berseberangan clengan tawaran konsep HAM yang lahir clari institusi, mulai clari yang mikro hingga yang makro(intitusi kenegaraan). Karena clalam prakteknya kecenderungan konsep HAM akan selalu berkaitan erat dengan kepentingan penguasa dari masing-masing pembuat konsep HAM tersebut.

Apakah clisebabkan karena tidlak berlakunya konsep Deklarasi Universal oleh sidlang umum PBB? Ataukah karena aclanya perbedaan konsep HAM sclari másingmasing negara?? Kalau clemiikian halnya mengapa tidak sesegera mungkin dibatasinya pemberlikuan konsep HAM sesuai clengan konteks Poleksosbudnya, sehingga Deklarasi Universal yang telah clicetuskan oleh sidlang Umum PBB menjadi ticlak berlaku lagi? Ataukah. disebabkan karena perbedaan konsep HAM yang climunculkan oleh masing-masing incliviclu? selingga batas-batas antara hak clan kewajiban antar masingmasing pribadi manusia telah clikaburkan oleh kepentingan individu mereka. Dan kemungkinan yang trakhir apakah karena lemahnya supremasi hukum clari masing-masing negara tersebut. Inilah yang lagilagimenjadi PR clari seluruh umat manusia di clunia ini, untuk membongkar rahasia clibalik misteri HAM.
Ini artinya jika HAM yang disepakati clicetuskan dari HAM internasional, maka pertanyaan yang hendak muncul adalah apakah HAM internasional yang clicetuskan oleh sidang umum PBB telah sampai pada tálraf universal, bisa melepaskan kepentingankepentingan clari negara-negara tertentu yang clianggap memiliki kekuatan, lebih-lebih kekuasaan (Mark R.Wood Ward,1998:240) ketika berhadlapan clengan kontek politik, buclaya, dan ékonomi suatu bangsa, lebih-lebih bangsa-bangsa di clunia ketiga yang relatif asing clengan peradlaban barat yang liberal, suatu peradaban yang seclemikian kapitalistik dan borjuistik.

Pertanyaan diatas nampaknya iclentik dengan kritik Menlu RI Ali al-Atas clalam acara konferensi Internasional HAM di Wina, Austria pada pertengahan bulan juni 1993, ia menyatakan bahwa"sebagian besar 
negara berkembang mendukung konsep universal HAM, namun mereka menentang nilai-nilai tertentu yang dianggapnya tidak relevan dengan kondisi negara masing-masing.

Letupan pertanyaan yang selalu muncul diatas, berikut kritik pedas yang tengah dilontarkan oleh Menlu RI Ali al-Atas dalam acara konferensi Intrnasional di Wina tujuh tahun yang lalu, merupakan satu indikasi tidak berlakunya konsep universal HAM yang selama ini telah kita cleklarasikan bersama melalui PBB. Hal demikian karena dalam aplikasinya konsep HAM yang dideklarasikan oleh PBB masih banyak clitunggangi oleh kepentingan-kepentingan sepihak. Tentu dalam hal ini adalah negaranegara barat yang seclemikian kapitalistik dan borjuistik tersebut.

Berangkat dari sini kita mesti mengkhayalkan lahirnya konsep HAM yang ideal, tentu konsep HAM yang mampu meneracakan nilai-nilai universal, yakni suatu konsep yang tetap memperhatikan tanggung jawab kita dihadapan Allah (vertikal) dan manusia(horisontal). Suatu

Jika kepentingan hampit menjadi
setandarisasi mekanisme hubungan
kemanusiaan, tentu takbisa tidak, unsur
kepentingan menurut versi masing:
masing yang lébih menguntungkan bagi
pihak-pihak yang terkuat akan segera
tampil (Wlark R. Wood Ward, 1998:240),
yang pada giliran selanjutnya akan terjadi
perebutan "tumpeng kepentingan" itu
sendiri, tanpa harus mempertimbangkan
bagaimana suatukepentingan didasarkan
pada hak dan kewajiban manusia secara.
fundamental (universal).

kepentingan tersebut harus meneracakan dirinya dengan keadilan dan nurani kemanusiaan yang universal pula (M. Luqman Hakiem,1993:3).

Disilah persoalannya, HAM lagi-lagi meniscayakan terlibatnya kepentingan-kepentingan manusia yang berakhir pada perebutan tumpeng kepentingan itu sendiri. Gejala inilah yang seharusnya selalu diwaspadai oleh pemerhati HAM. Karena tidak menutup kemungkinan neraca keadilan dan nurani kemanusiaan secara universal yang senantiasa diteriakkan oleh pemerhati dan antosiasme HAM akan segera musnah, clisebabkaṇ badai kepentingan manusia yang selalu menggoncangnya.

Tarik menarik dari sekelompok orang yang murni memperjuangkan HAM clan orang yang selalu menyelipkan kepentingannya sendiri dengan mengatasnamakan pembelaan HAM adalah sulit untuk dicleteksi. Dan ia merupakan oknum yang selalu muncul sepanjang perjalanan sejarah ditegakkannya HAM. Dengan demikian tugas kita sekarang ticlak sajal untuk konsep yang membuang jauh-jauh dari kepentingan manusiawi yang suclah terlilit oleh sifat angkara murkanya.

Jika kepentingan hampir menjadi setandarisasi mekanisme hubungan kemanusiaan, tentu tak bisa tidak, unsur kepentingan menurut versi masing-masing yang lebih menguntungkan bagi pihak-pihak yang terkuat akan segera tampil (Mark R.Wood Ward,1998:240), yang pada giliran selanjutnya akan terjadi perebutan "tumpeng kepentingan" itu sendiri, tanpa harus mempertimbangkan bagaimana suatu kepentingan didlasarkan pada hak dan kewajiban manusia secara fundamental (universal).

Ini artinya kepentingan memang merupakan keniscayalan yang tak , terhindarkan dari pergulatan manusia.Sayangnya ukuran kepentingan yang dimaksud begitu mudah untuk dikaburkan oleh semboyan-semboyan semu. Karenanya secara icleal mensosialisasikan HAM clalam clataran praksis, selalu muncul dari interen.Dan tugas yang kedua ini nampaknya merupakan tugas kita yang lebih berat jika dibanding dengan sosialisasi HAM.Karena pada hakekatnya hampir semua manusia yang normal sepakat akan clitegakkannya konsep uniersal HAM.

Namun clalam kenyataannya kepentingan manusia masih mencluduki peringkat teratas, akibatnya, kebenaran dan keadilan universal masih menjadi jargon an sich, clan belum merealita, sepanjang kepentingan itu dikuasai oleh penguasapenguasa jahiliyah. Sebuah kekuasaan yang ticlak asing lagi melakukan perlawanan hukum.Konteks seperti ini sering terjadi pada suatu kondisi climana supremasi hukum telah mengalami keloyoan.

Untuk memperkuat argumen diatas akan kami hadirkan contoh real yang membuktikan adanya melainkan memberantas bahaya-bahaya laten yang 
perbedaan mencolok tentang penyikapan HAM antara Indonesia dengan Filipina. Kedua negara tersebut jika kita lihat dari tingkat pendapatan perkapitanya tidak jauh berbeda, kedua-cluanya sama-sama negara sedang berkembang dan beracla clalam satu rumpun bangsa Asia.Kata seorang Doktor yang sedang bertugas di Filipina, bahwa masyarakat yang berdemonstrasi disana hampir setiap hari menghiasi surat kabar Filipina. Namun satu hal yang sangat berbeda jika dibandingkan dengan model demo yang terjadi di tanah air, demo yang terjadi di Filipina ticlak pernah berakhir dengan perusakan, pembakaran, penganiayaan, pemerkosalan dan penjarahan: Sebaliknya demo di Indonesia selalu diakhiri dengan tindakan melawan hukum. Mengapa itu terjadi? (Dr. Soekartawi,Berdemo Tanpa Merusak, dalam Surya/4/3/ 2000.Halaman 11)

Membandingkan peristiwa clikedua negara tersebut menurutnya tidak terlalu ariff, karena ditilik dari berbagai aspek kedua-cluanya hampir memiliki status yang seimbang. Fenomina diatas sempat

Dengan demikian demonstrasi yang berkembang di Indonesia disatu sisi bisa dimaknai sebagai bentuk tuntutan atas hakmereka yang didasarkan pada neraca keadilan universal. Dilain pihak demontrasi yang terjadi di Indonesia lebih dimaknai sebagai kendaraan politik yang lebih akrab dengan kepentingan-kepentingan sepihak. menjadi persoalan yang menghantui pemikirannya, hingga berakhir clengan pernyataan yang ia lontarkan kesalah seorang guru besar yang ada di Filipina. Menurut guru besar tersebut adanya perbedaan yang mencolok diatas disebabkan karena orang-orang Inclonesia terlalu banyak makan cabe, dan ticlak pernah ada evaluasi clari pengaruh cabe yang telah dimakannya.Tafsir dari ungkapán diatás bermakna adanya kebiasalan negatif (keras kepala) yang telah membudaya dikalangan masyarakat Indinesia sebelum mereka melakukan demonstrasi. Sehingga tindakantindakan melawan hukum, tidak lagi dianggap sebagai persoalan yang memghantui gerakan mereka. Tindakan ini tetap berkembang dengan peșatnya, karena tindakan semacamnya tidak pernah segera diatisi oleh hukum yang telah clitegakkan, akibatnya wibawa hukum menjadi meleinah dan terkadlang disalahmengertikan.
Argumentasi guru besar Filipina diatas merupakan satu diantara tafsir/analisanya. Jika penulis ikut berembuk clidalamnya tentu berbecla lagi pendekatan analisanya. Sikap negatif yang telah mentradisi di Indonesia dalam fenomena demontrasi, karena kebanyakan dari mereka suclah ditunggangi dengan nilai-nilai kepentingannya. Demontrasi yang semula bermakna positif, yakni sebagai ungkapan kritis masyarakat untuk melakukan pengontrolan dari beberapa tindakan yang menyimpang hukum, berubah menjadi multy interpretation.

Dengan demikian demonstrasi yang berkembang di Indonesia disatu sisi bisa climạknai sebagai bentuk tuntutan atas hak mereka yang cliclasarkan pada neraca keadilan universal. Di lain pihak demontrasi yang terjacli di Indonesia lebih dimaknai sebagai kendaraan politik yang lebih akrab dengan kepentingan-kepentingan sepihak. Bagi kelompok yang kedua ini, tuntutan hak-haknyal sering berbenturan clengan hak-hak masyarakat umum, bahkan tuntutantuntutan hak ciari kelompok ini ternyata telah membatasi ribuan hak-hak orang lain yang akan melangsungkan kehidupannya.

Pada saat yang sama berarti mereka telah menafsirkan HAM tuncluk atas kepentingan indificlualnyal, dan bukan kepentingan yang sarat dengan neraca nilai-nilai keadilan universal. Inilah yang menurut argumen di atas clianggap sebạgai kekuasaan-kekuasalan jahiliyah. Sepanjang penguasapenguasa jahiliyah ini menguasai masyarakat manusia pada umumnya, naka eksistensi HAM universal yang sejak mulanya diiclealkan oleh manusia tidlak akan pernah merekal rasakan. Disinilah akhirnya manusia pacla hakekatnya ingin kembali ke konsep HAM universal. Dan itu tidak akan pernah terwujud jika konsep HAM yang adla menafikan peran agamanya. 


\section{HAM Dalam Pandangan Islam}

Isu internasional yang paling mencekam tentang HAM, selamanya tidak akan pernah reda, sejauh isu tersebut hanya didekati lewat tarik menarik kepentingan politik, ekonomi, budaya dan hankam. Sebab pada kenyataannya, dalam sejarah kehiclupan manusia ini, belum ditemukan sekelompok orang yang mampu membendung gugatan-gugatan naluri emosinya sendiri, bahwa mereka punya hak dan sekaligus kewajiban yang sering berseiringan. Oleh sebab itu kesadaran akan hak clan kewajiban ini menjadifenomena yang amat sakral dalam kehidupan kesehariannya. Itu penting, clan ia akan bisa terwujud tergantung pada pertimbangan sejauh mana HAM itu memiliki muatan-muatan relegius.

Dimensi ini hingga kini dirasa merupakan persoalan yang amat urgen, karena dimensi itulah yang selalu mengkaitkan fenomena kehidupannya clengan tanggung jawab vertikal.

Dengan demikian bisa ditarik kesimpulan bahwa cakrawala yang dihadirkan dalam perspektif HAM Islam, senantiasa menyiratkan clua

Dengan demikian bisa ditarik kesimpulan bahwa cakrawala yang dihadirkan dalam perspektif HAMlsiam, senantiasa menviratkan dua titik pandang, di salu pihak terbentang horison sejarah menjadi "kaki langit" tegaknya perdamaiandunia, di lain pihak menegakkan garis lur us keatas, bahwa bagaimanapun HAMI menjadi bagian vertikal yang sakral dan titri,tentu mesti melibatkan Kekuatan transendental dari tangan-tangan Tuhan (Luqman Hakiem, Ed, 1993:191) titik pandang, di satu pihak terbentang horison sejarah menjacli "kaki langit" tegaknya perdamaian dunia, di lain pihak menegakkan garis lurus keatas, bahwa bagaimanapun HAM menjadi bagian vertikal yang sakral clan fitri,tentu mesti melibatkan kekuatan transendental dari tangan-tangan Tuhan (Luqman Hakiem, Ed, 1993:191). Ini berarti pembelaan terhadap HAM yang acla pada diri manusia sejak kelahirannya hampir bisa dirasakan oleh mereka. Selanjutnya kita agak bernacla optimis ketika menghadapi cakrawala HAM dalam peraspektif Islam tersebut.

Secara jujur Dr.Abclul Mun'im Al-Bahy mengatakan bahwa jauh sebelum HAM PBB itu didengungkan, 14 Abad silam, secara sempurna Tuhan telah memproklamirkan HAM universal yang mengatur tata clunia clan peraclaban manusia(al'Arabiyah Li al-Nasyi'iin, 1983:jilid 5:241). HAM tersebut dicleklarasikan lewat utusan-utusannya,
Muhammad SAW misalnya, lewat ajaran-ajaran AlQur'an clan sunahnya. clan itulah sebagai wujud dari Deklarasi HAM Islam.

Di dalam syari'at Islam juga diungkapkan bahwa manusia adalah makhluk bebas yang punya tugas clan tanggung jawab. Karenanya layak jika mereka memiliki hak clan kebebasan, yang berdasar atas keadilan yang ditegakkan dengan misi persamaan atau egaliter, tanpa pandang bulu. Ini berarti tugas yang cliembannya tak akan pernah terealisir tanpa adanya kebebasan. Sebaliknya kebebasan secara eksistensi juga tidak pernah ada tanpa tanggung jawab itu sencliri (Anthony Giddens, 1999 :75)

Dengan clemikian HAM dalam Islam tidak pernah diduga sebagai produc historik yang muncul dari pemikiran ideologis, melainkan ia memiliki climensi teologis. Tentu kelak ini semua akan dipertanggung jawabkan dihadapan Ilahi. Secara kasarnya HAM dalam pandangan Islam bukanlah sebagai akibat dari perkembangan politik, melainkan hak asasi yang tertuang secara transeclen untuk kepentingan manusia melalui syari'at Islam yang cliturunkan lewat wahyu-Nya. Dimana ini semua disemangati oleh satu keyakinan untuk mengangkat harkat kemanusiaan sebagai makhluk yang luhur.

\section{Daftar Pustaka}

Al-Qur'an

M.Luqman Hakiem, Ed, 1993, Deklarasi Islam Tentang HAM, Risalah Gusti, Surabaya

Anthony Giddens, 2000, The Third Way, Gramedia Pustaka Utama, Jakarta

Mark R.Woodward, 1998, Jalan Baru Islam, Mizan, Bandung Mohammad Arkoun, 1999, Membongkar Wacana Heqemonik, AL fikri, Surabaya

Dale F.Eickelmen \& James Piscatori, 1998, Ekpresi Politik Muslim, Mizan, Bandung

Mohammad Ismail Soyyani, 1983, AL-Arobiyah Li-ALNasyi'in, iclaratul Kutub AL-Maclrasiya, AL Su'ucliyah.

Suekartawi, 2000, Berdemo Tanpa Merusak, Surya/ $\mathbf{4} / 3 / 2000$ 